\title{
Antibacterial Activity of Coastal Plants and Marine Sponges from Kei Island Indonesia against Bacterial Fish Pathogens
}

\author{
Andi Hamdillah', Alim Isnansetyo ${ }^{1, *}$, Indah Istiqomah', Indun Dewi Puspita' ${ }^{1}$, Desy Putri Handayani' ${ }^{1}$, Takushi \\ Kaneko²
}

\author{
Andi Hamdillah', Alim \\ Isnansetyo ${ }^{1, *}$, Indah \\ Istiqomah ${ }^{1}$, Indun Dewi \\ Puspita', Desy Putri \\ Handayani', Takushi Kaneko²
}

'Department of Fisheries, Faculty of Agriculture, Universitas Gadjah Mada, Jl. Flora, Bulaksumur, Yogyakarta, INDONESIA. ${ }^{2}$ Global Alliance for TB Drug Development, Research and Development, 40 Wall Street, 24th Floor, New York, NY, USA.

\section{Correspondence}

\section{Alim Isnansetyo}

Department of Fisheries, Faculty of Agriculture, Universitas Gadjah Mada, JI. Flora, Bulaksumur, Yogyakarta, INDONESIA.

E-mail: isnansetyo@ugm.ac.id

History

- Submission Date: 08-03-2019;

- Review completed: 04-04-2019;

- Accepted Date: 30-04-2019

DOI : 10.5530/pj.2019.11.130

Article Available online

http://www.phcogj.com/v11/i4

\section{Copyright}

(๔) 2019 Phcogj.Com. This is an openaccess article distributed under the terms of the Creative Commons Attribution 4.0 International license.

\begin{abstract}
Objective: The objective of this study was to investigate the antibacterial activity of coastal plants and marine sponges extracts against fish bacterial pathogens. Methods: Samples were extracted by maceration and the extracts were examined for their antibacterial activities against Streptococcus sp. BJ0509, Staphylococcus aureus ATCC 6538, Aeromonas hydrophila BA03 and Vibrio parahaemolyticus 295 by means of paper disc diffusion method. Active extracts were partitioned and purified by column chromatography. The purified substance was tested for minimum inhibitory concentration (MIC) against seven bacterial fish pathogens namely Streptococcus sp., Vibrio parahaemolyticus, V. alginolyticus, V. harveyi, Photobacterium damselae, Aeromonas hydrophila and A. dhakensis. Results: The highest antibacterial activity against all bacteria used in the assay was demonstrated by OKA 6, a bark extract sample of a coastal plant, Diospyros maritima. It showed a diameter of inhibition zones against Streptococcus sp. BJ0509, S. aureus ATCC 6538, A. hydrophila BA03 and V. parahaemolyticus $29 S$ of $19,33,18$, and $18 \mathrm{~mm}$, respectively. The column chromatography fraction of OKA 6 inhibited the growth of S. aureus ATCC 6538 with MIC of $3.125 \mu \mathrm{g} / \mathrm{mL}$. The MIC of this fraction against seven bacterial fish pathogens ranged $<0.098$ to $3.125 \mu \mathrm{g} / \mathrm{mL}$. The antibacterial activity of partially purified substance obtained from column chromatography fractionation of OKA 6 was higher than those of oxytetracycline and kanamycin. Conclusions: This result indicates that antibacterial activity of the partially purified substance is potentially higher than those of the commercial antibiotics tested. It further indicates that OKA 6 extract from D. maritima can serve as a promising resource for the development of therapeutic agents against bacterial infections in aquaculture.

Key words: Antibacterial activity, Secondary metabolite, Coastal plant, Marine sponge, Fish pathogen, Bacteria
\end{abstract}

\section{INTRODUCTION}

Coastal plants and sponges are marine resources that have been widely known as producers of bioactive compounds. ${ }^{1-3}$ They are rich sources of alkaloids, saponins, tannins, flavonoids, terpenoids, and glycosides ${ }^{1,4}$ many of which exhibit various bioactivities including anticancer, ${ }^{5}$ antifungal, ${ }^{2,3,6}$ antiviral, ${ }^{4}$ antioxidant ${ }^{7-9}$ and antibacterial activities. $^{2,4,6,8,10,11}$ The application of antibacterial compounds from coastal plants and sponges are not only limited in medication of disease caused by human pathogenic bacteria ${ }^{12,13}$ but also have been applied to overcome the problem of fish bacterial infections. ${ }^{2,12}$

Fish infection by pathogenic bacteria would cause a serious economic loss in aquaculture as it causes a negative impact either on the growth and survival rates of fishes. ${ }^{14-18} \mathrm{~A}$ common practice to overcome the problem of bacterial diseases in fish is by administering antibiotics. ${ }^{19,20}$ However, long-term uses of antibiotics and improper doses have caused bacterial resistance. ${ }^{20-22}$ Therefore, a search for new compounds is important in overcoming the problem of bacterial infections in aquaculture. $^{3,6,13,23}$
Indonesia is known as an archipelagic country with mega biodiversity. Kei Islands, one of the 117 islands in Southeast Maluku Region, Maluku Province, possess a great potency of its coastal and marine resources. To the best of our knowledge, research on the antibacterial substances from coastal plants and sponges from Kei Islands has never been conducted. When we screened coastal plants and sponges from this island for anti-tuberculosis activity, we also found several extracts active against fish pathogenic bacteria. The purposes of this study were to extract secondary metabolites from the coastal plants and sponges, to evaluate antibacterial activity, and to partially purify the potential substances.

\section{MATERIALS AND METHODS}

\section{Sample collection}

Samples were collected in May 2017 at Ohoi Kelanit (S-5 ${ }^{\circ} 39^{\prime} 18,34^{\prime \prime}$ E $\left.132^{\circ} 40^{\prime} 48,32\right)$ and Ohoi Letman (S - $5^{\circ} 34^{\prime} 43,67^{\prime \prime}$ E $\left.132^{\circ} 43^{\prime} 20,18\right)$, Kei Islands, Southeast Maluku Regency, Maluku. Freshlycollected specimen of sponges and part of coastal plants including barks, leaves, fruits, and twigs were immediately transported to the laboratory. A total of 32 samples were washed with water to remove

Cite this article: Hamdillah A, Isnansetyo A, Istiqomah I, Puspita ID, Handayani DP, Kaneko T. Antibacterial Activity of Coastal Plants and Marine Sponges from Kei Island Indonesia against Bacterial Fish Pathogen. Pharmacog J. 2019;11(4):812-7. 
adhering soil particle and salts, air-dried, chopped into small pieces and ground coarsely into a powder in a mechanical grinder.

\section{Preparation of crude extracts}

An amount of $20 \mathrm{~g}$ powdered samples were extracted using maceration method with $80 \mathrm{~mL}$ solvents for $24 \mathrm{~h}$ and the process was repeated three times. Two types of solvent were used, ethanol and ethyl acetate. The soluble parts of extracts were filtered using Whatman paper, evaporated using rotary evaporator (Heidolph) at $40^{\circ} \mathrm{C}$, and air-dried in shade for 3 days. The crude extracts were stored at $4^{\circ} \mathrm{C}$ prior to use.

\section{Bacterial strains and media}

Eight bacteria were used in the antibacterial activity assay, namely Streptococcus sp. BJ0509 and Staphylococcus aureus ATCC 6538, as representatives of Gram-positive bacteria, Aeromonas hydrophila BA03, A. dhakensis SB01, Vibrio parahaemolyticus 29S, V. alginolyticus GD22, V. harveyi GD38 and Photobacterium damselae SB25 as representatives of Gram negative bacteria. All isolates were bacterial collections of Laboratory of Fish Health Management, Department of Fisheries, Faculty of Agriculture, Universitas Gadjah Mada, except S. aureus ATCC 6538. All bacteria were stored in TSB (Oxoid, UK) medium containing $20 \%(\mathrm{v} / \mathrm{v})$ glycerol, except Vibrio spp. and P. damselae SB25, which were stored in Zobell broth medium, ${ }^{24}$ and stored frozen at $-80^{\circ} \mathrm{C}$.

\section{Antibacterial activity assay}

The extracted samples from previous step were screened for their antibacterial activity. Antibacterial activity assay was carried out against Streptococcus sp. BJ0509, Staphylococcus aureus ATCC 6538, Aeromonas hydrophila BA03, and Vibrio parahaemolyticus 29S, using the paper disc diffusion method on double layer agar. ${ }^{25}$ The bacterial inoculums were prepared in TSB (Oxoid, Japan), except V. parahaemolyticus 29S was in Zobell broth. Before inoculation, the cell density was estimated based on McFarland standard using spectrophotometer (Apel, Japan) at $\lambda$ $625 \mathrm{~nm}$. Inoculum of $10^{6}$ cells $/ \mathrm{mL}$ were transferred into TSB (Oxoid, UK) added with 0.7\% agar for Streptococcus sp. BJ0509, S. aureus ATCC 6538, and A. hydrophila BA03; and Zobell medium added with $0.7 \%$ agar for Vibrio spp. and Photobacterium damselae SB25. Then, the mixtures were poured into TSA (Oxoid, UK) or Zobell agar medium. Sterile paper disks (e $8 \mathrm{~mm}$, Advantec, Tokyo) were dripped with 50 $\mu \mathrm{L}$ of extracts, placed on the surface of inoculated agar, and incubated at $30^{\circ} \mathrm{C}$ for $24 \mathrm{~h}$. Antibacterial activity was measured based on the diameter of the inhibition zone.

\section{Partition of crude extract}

The crude extract showing the highest antibacterial activity was continued for partition. The crude extract in a powder form was dissolved in $50 \mathrm{ml}$ ethanol (96\%) and added with distilled water by 1:1 $(\mathrm{v} / \mathrm{v})$ and partitioned with $50 \mathrm{ml}$ chloroform:distilled water $(1: 1, \mathrm{v} / \mathrm{v})$ in a separating funnel. The mixture was shaken slowly until two layers were formed. The bottom layer was collected as the chloroform fraction and the process was repeated three times. Chloroform fraction was evaporated under reduced pressure and dried. Its antibacterial activity was confirmed by the paper disc diffusion assay as described previously and stored at $4^{\circ} \mathrm{C}$ prior to purification.

\section{Column chromatography}

One gram of the chloroform fraction was dissolved in $1 \mathrm{~mL}$-Hexane: Chloroform: Ethanol (7:2:1) and purified using silica gel column chromatography (column diameter of $3 \mathrm{~cm}$ and length of $30 \mathrm{~cm}$ ). Silica gel $\mathrm{F}_{254}$ (60; particle size: 0.065-0.200 mm) (Merck, Germany). The sample was dissolved with $96 \%$ ethanol, and then poured carefully into the chromatography column. The chloroform fraction of $1 \mathrm{~mL}$ was applied into the column, and eluted subsequently by solvent combination of n-hexane:chloroform:ethanol (7:2:1 and 4:5:1) and ethanol (100\%). The column fractions were tested for antibacterial activity.

\section{Measurement of MIC and MBC of column fraction}

The fraction obtained from the column chromatography showing the highest antibacterial activity was determined for its minimum inhibitory concentration (MIC) and minimum bactericidal concentration (MBC). The MIC was evaluated against Streptococcus sp. BJ0509, Staphylococcus aureus ATCC 6538, Aeromonas hydrophila BA03, A. dhakensis SB01, Vibrio parahaemolyticus 29S, V. alginolyticus GD22, V. harveyi GD38 and Photobacterium damselae SB25 using microdilution method. ${ }^{26}$ While the measurement of MBC were performed against Streptococcus sp. BJ0509 and V. parahaemolyticus 29S. Known antibiotics, Oxytetracycline (Sigma, Japan) and Kanamycin (Wako, Japan), were used as positive controls. Fraction was tested at concentrations starting from $0.098 \mu \mathrm{g} / \mathrm{mL}$ to $50 \mu \mathrm{g} / \mathrm{mL}$. A total of $100 \mu \mathrm{L}$ (bacterial suspension $10 \mu \mathrm{L}, 2$ strength of Mueller Hinton Broth (MHB) $50 \mu \mathrm{L}$ and samples or antibiotics $40 \mu \mathrm{L}$ ) were mixed in each well of 96-well microplate and incubated for $24 \mathrm{~h}$ at $30^{\circ} \mathrm{C}$. MBC was tested by inoculating $20 \mu \mathrm{L}$ of test samples from 96-well microplate on Mueller Hinton (Conda, India) Agar (MHA) plate and incubated for another $24 \mathrm{~h}$ at $30^{\circ} \mathrm{C}$.

\section{RESULTS AND DISCUSSION}

\section{Screening of antibacterial activity from coastal plants} and sponges

This paper describes the antibacterial activity of several coastal plants and marine sponges. The results of the primary screening for antibacterial activities from 63 crude extracts showed that only three samples (OKA 6, OLS 7, and OLS 8) (Table 1) exhibited promising antibacterial activities. OKA 6, sample extract with the highest antibacterial activity, was bark of coastal plant that collected from Ohoi Kelanit (S -5 $\left.39^{\prime} 18,34^{\prime \prime} \mathrm{E} 132^{\circ} 40^{\prime} 48,32\right)$. The leaves are shiny dark green and egg-shaped with rounded tips (Figure 1). The outer surface of bark of the plant was dark (black).

From a total of 63 extracts, there were $8 \%$ of crude extracts showing high antibacterial activity with inhibition zones diameter more $19 \mathrm{~mm}$ against V. parahaemolyticus 29S and 2\% against S. aureus ATCC 6538 (Figure 2). The second and the third highest antibacterial activities were shown by the ethyl acetate extracts of two different sponges, encoded OLS 7 and OLS 8, but the highest antibacterial activity was shown by the ethanol extract of the bark obtained from a coastal plant, OKA 6, with $33 \mathrm{~mm}$ in diameter of inhibition zone against $S$. aureus ATCC 6538, $19 \mathrm{~mm}$ against Streptococcus sp. BJ0509, $18 \mathrm{~mm}$ against $A$. hydrophila BA03 and $18 \mathrm{~mm}$ against $V$. parahaemolyticus $29 \mathrm{~S}$ (Table 1). The OKA 6 plant was identified to be Diaspyros maritima.

Table 1: Diameter of inhibition zone $(\mathrm{mm})$ of active crude extracts of coastal plants and sponges $(1000 \mu \mathrm{g} / \mathrm{disk})$ from a total of 63 extracts against bacterial test.

\begin{tabular}{cccc}
\hline \multirow{2}{*}{ Bacteria } & Plant (Bark) & \multicolumn{2}{c}{ Sponges } \\
\cline { 2 - 4 } & $\begin{array}{c}\text { Ethanol } \\
\text { extract of } \\
\text { OKA 6 }\end{array}$ & $\begin{array}{c}\text { Ethyl acetate } \\
\text { extract of OLS 7 }\end{array}$ & $\begin{array}{c}\text { Ethyl acetate } \\
\text { extract of OLS 8 }\end{array}$ \\
\hline Streptococcus sp. BJ0509 & 19 & 11 & 12 \\
S. aureus ATCC 6538 & 33 & 18 & 18 \\
A. hydrophila BA03 & 18 & 9 & 11 \\
V. parahaemolyticus 29S & 18 & 13 & 0 \\
\hline
\end{tabular}

Diameter of paper disc $(\theta)=8 \mathrm{~mm}$ 


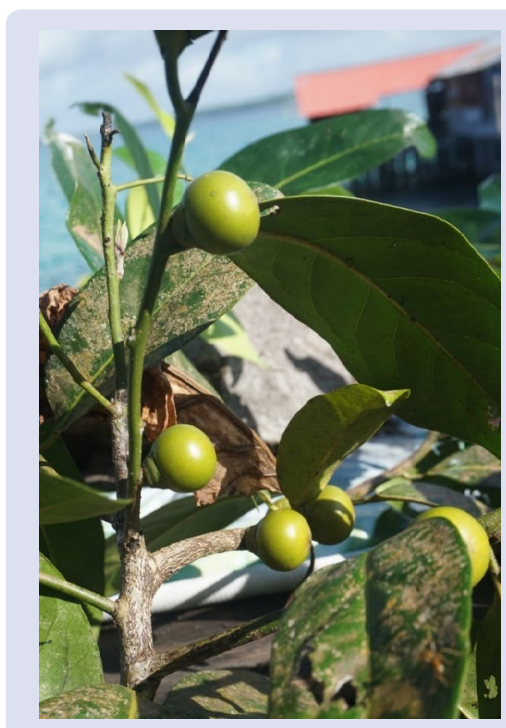

Figure 1: The plant of OKA 6.

A

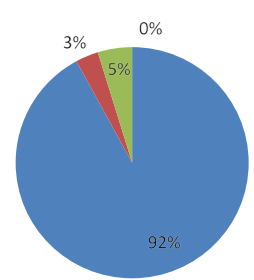

C

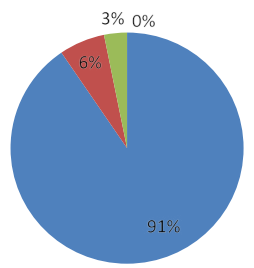

Figure 2: The distribution of antibacterial activity of coastal plants and marine sponges crude extracts against (A) Streptococcus sp. BJ0509, (B) S. aureus ATCC 6538, (C) A. hydrophila BA03, and (D) V. parahaemolyticus 295 .

The antibacterial activities of bark extracts from the coastal plants had been reported previously. Arivuselvan et al. evaluated the antibacterial activity of bark extract of coastal plants. ${ }^{27}$ Bark extract of Ceriops tagal inhibited V. parahaemolyticus and S. aureus with the MIC of 125 and $75 \mu \mathrm{g} / \mathrm{mL}$, and Pemphis acidula inhibited V. parahaemolyticus and $S$. aureus with the MIC of 150 and $150 \mu \mathrm{g} / \mathrm{mL}$, respectively. In comparison to our study, bark extract of OKA 6 has a lower MIC than Criops tagal and Pemphis acidula. Another studies also showed that barks from coastal plant have an antimicrobial activity, such as Sonneratia apetala and S. caseolaris. ${ }^{28}$

\section{Fractionation of the highest active extract, OKA 6}

As the ethanol extract of OKA 6 exhibited highest antibacterial activity, this extract was proceeded to further fractionation by partition and open column chromatography. The fractionation was carried out by partition and open column chromatography. Partition step resulted the chloroform fraction with high antibacterial activity against all tested bacteria. As shown in Table 2, the antibacterial activity of this fraction was comparable to a positive control, oxytetracycline. The diameter of inhibition zone produced by OKA 6 chloroform fraction at $1,000 \mu \mathrm{g} /$ disk was up to $38 \mathrm{~mm}$ against Streptococcus sp. BJ0509, meanwhile the positive control only exhibited $26 \mathrm{~mm}$ of inhibition zone against the same bacterial strain at $100 \mu \mathrm{g} / \mathrm{disk}$.

The further purification of OKA 6 chloroform fraction was conducted by column chromatography eluted with three solvent combinations of $n$-hexane:chloroform:ethanol (7:2:1 and 4:5:1). The results of antibacterial activity assay of the OKA 6 fractions indicated that the active compound responsible for the antibacterial activities were eluted in the fraction number 4 to 11 (Figure 3).

\section{MIC and MBC}

The active fraction obtained from column chromatography showed antibacterial activity with MIC of $3.125 \mu \mathrm{g} / \mathrm{mL}$ against Streptococcus sp. BJ0509 and $1.563 \mu \mathrm{g} / \mathrm{mL}$ against $V$. parahaemolyticus 29S, whereas the MICs of two antibiotics, oxytetracycline and kanamycin, were $6.25 \mu \mathrm{g} /$ $\mathrm{mL}$ and $6.25 \mu \mathrm{g} / \mathrm{mL}$ against Streptococcus sp. BJ0509; and $6.25 \mu \mathrm{g} / \mathrm{mL}$ and $6.25 \mu \mathrm{g} / \mathrm{mL}$ against $V$. parahaemolyticus $29 \mathrm{~S}$, respectively (Table 3 ). The MBCs of the fraction were $12.5 \mu \mathrm{g} / \mathrm{mL}$ against Streptococcus sp. BJ0509 and $6.25 \mu \mathrm{g} / \mathrm{mL}$ against $V$. parahaemolyticus 29S, whereas the MBCs of two antibiotics, oxytetracycline and kanamycin, were $25 \mu \mathrm{g} /$ $\mathrm{mL}$ and $>50 \mu \mathrm{g} / \mathrm{mL}$ against Streptococcus sp. BJ0509; and $25 \mu \mathrm{g} / \mathrm{mL}$ and $>50 \mu \mathrm{g} / \mathrm{mL}$ V. parahaemolyticus $29 \mathrm{~S}$, respectively (Table 3 ). The column chromatography fraction of OKA 6 against six other bacterial fish pathogens of Vibrio spp, Aeromonas spp and P. damselae SB25 were in the range of $<0.098$ to $0.391 \mu \mathrm{g} / \mathrm{ml}$. The MICs and MBCs exhibited that OKA 6 fraction from column chromatography were lower than two commercial antibiotics, oxytetraciline and kanamycin indicating that the fraction was more potent than those of two commercial antibiotics.

A number of research reported the MIC of bark extract from several plants. The MIC of chloroform extract of Sonneratia caseolaris bark

Table 2: Antibacterial activity of OKA 6 chloroform fraction.

\begin{tabular}{ccccc}
\hline \multirow{2}{*}{ No. } & Bacteria & \multicolumn{3}{c}{ Diameter of inhibition zone (mm) } \\
\cline { 3 - 5 } & $\begin{array}{c}1000 \mu \mathrm{g} / \\
\text { disk }\end{array}$ & $\begin{array}{c}500 \mu \mathrm{g} / \\
\text { disk }\end{array}$ & $\begin{array}{c}\text { Positive } \\
\text { Control" }\end{array}$ \\
\hline 1 & A. hydrophila BA03 & 24 & 19 & 10 \\
2 & Streptococcus sp. BJ0509 & 38 & 26 & 26 \\
3 & S. aureus ATCC 6538 & 32 & 30 & 21 \\
4 & V. parahaemolyticus 29S & 27 & 22 & 12 \\
\hline
\end{tabular}

"Control $=$ oxytetracycline $(100 \mu \mathrm{g} / \mathrm{disk})$

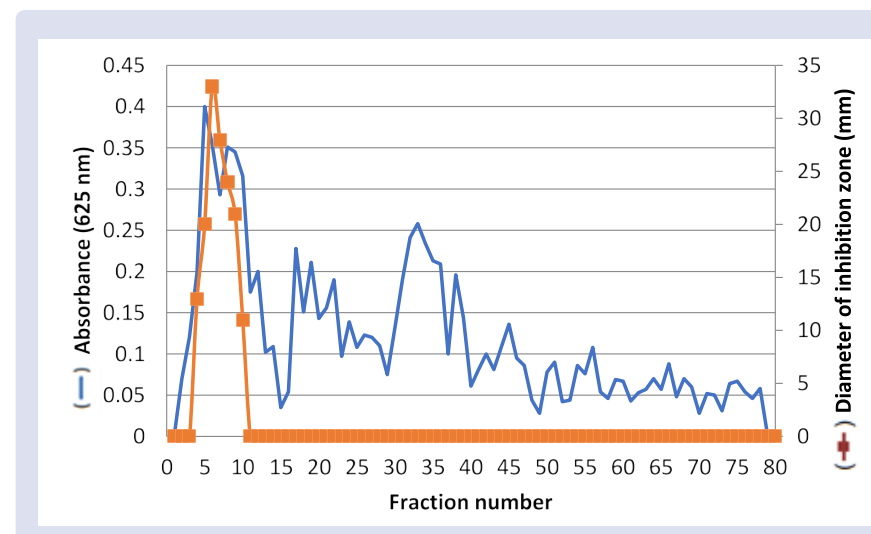

Figure 3: The Absorbance and antibacterial activity of column chromatography fractions of OKA 6 against S. aureus. ATCC 6538. 
Table 3: MICs and MBCs of active compound.

\begin{tabular}{|c|c|c|c|c|c|c|}
\hline \multirow{2}{*}{ Bacterial } & \multicolumn{3}{|c|}{$\mathrm{MIC}(\mu \mathrm{g} / \mathrm{mL})$} & \multicolumn{3}{|c|}{$\mathrm{MBC}(\mu \mathrm{g} / \mathrm{mL})$} \\
\hline & OKA 6-F7 & OTC & Kan & OKA 6-F7 & OTC & Kan \\
\hline Streptococcus sp. BJ0509 & 3.125 & 6.25 & 6.25 & 12.5 & 25 & $>50$ \\
\hline S. aureus ATCC 6538 & 3.125 & 1.563 & 12.5 & & & \\
\hline V. parahaemolyticus $29 \mathrm{~S}$ & 1.563 & 6.25 & 6.25 & 6.25 & 25 & $>50$ \\
\hline$V$. alginolyticus GD22 & $<0.391$ & 0.781 & 6.25 & & & \\
\hline V. harveyi GD38 & $<0.098$ & 3.125 & 0.391 & & & \\
\hline P. damselae SB25 & $<0.391$ & 3.125 & 6.25 & & & \\
\hline A. hydrophila BA03 & $<0.391$ & 3.125 & 3.125 & & & \\
\hline A. dhakensis SB01 & $<0.098$ & $>25$ & 1.563 & & & \\
\hline
\end{tabular}

OKA 6-F7 = column chromatography active fraction of OKA 6

OTC = oxytetracyline

Kan $=$ kanamycin

was $7.81 \mathrm{mg} / \mathrm{mL}$ against Bacillus coagulans ${ }^{7}$ and the ethanolic extract of Pempis acidula bark was $190 \mu \mathrm{g} / \mathrm{mL}$ against Vibrio parahaemolyticus. ${ }^{27}$ This MIC was much higher than MIC of OKA 6 fraction. Stem bark of Croton floribundus, Cariniana legalis and Myrcia velutina inhibited growth of Flavobacterium columnare dan Aeromonas hydrophila with MIC of $93.75 \mu \mathrm{g} / \mathrm{mL}$ to $375 \mu \mathrm{g} / \mathrm{mL} \cdot{ }^{29}$ In contrast, MICs of Ficus ovata bark ethanol extract against $S$. aureus and $E$. coli has been reported to be $>624 \mu \mathrm{g} / \mathrm{mL} .{ }^{30}$ Our work indicated that the bark extract of a plant OKA 6 was a potential resource for antibacterial agent against bacterial infections in aquaculture. The further attempt are required to scale up the purification of the active compound, to elucidate the chemical structure, to determine the cytotoxicity and therapeutics effectiveness of the compound against fish bacterial pathogens.

\section{ACKNOWLEDGEMENT}

This research was supported financially by the Global Alliance for TB Drug Development (TB ALLIANCE), 40 Wall Street, $24^{\text {th }}$ floor, New York, NY, USA. Special thanks to Drs. Wiyono, M.Si (a faculty member of Faculty of Forestry Universitas Gadjah Mada) for his help to identify the OKA 6 plant.

\section{REFERENCES}

1. Edu EAB, Edwin-Wosu NL, Udensi OU. Evaluation of bioactive compounds in mangroves: A panacea towards exploiting and optimizing mangrove resources. Journal of Natural Sciences Research. 2015;5(23):1-9.

2. Manilal A, Tsalla T, Zerdo Z, Ameya G, Merdekios B, John SE. Evaluating the antibacterial and anticandidal potency of mangrove, Avicennia marina. Asian Pacific Journal of Tropical Disease. 2016;6(2):136-40.

3. Mehbub MF, Michael VP, Wei Z, Christopher MMF. New marine natural products from sponges (porifera) of the order dictyoceratida ( 2001 to 2012 ); A promising source for drug discovery, exploration and future prospects. Biotechnology Advances. 2016:1-19.

4. Bhimba V, Meenupriya J, Joel EL, Naveena DE, Kumar S, Thangaraj M. Antibacterial activity and characterization of secondary metabolites isolated from mangrove plant Avicennia officinalis. Asian Pacific Journal of Tropical Medicine. 2010;3(7):544-6.

5. Uzma F, Mohan CD, Hashem A, Konappa NM, Salomone S. Endophytic fungi-alternative sources of cytotoxic compounds: A review. Frontiers in pharmacology. 2018;9:1-37.

6. Yang $F$, Hamann MT, Zou Y, Zhang M, Gong X, Xiao J, et al. Antimicrobial metabolites from the paracel islands Sponge agelas Mauritiana. Journal of Natural Products. 2012;2(75):774-8.

7. Simlai A, Rai A, Mishra S, Mukherjee K, Roy A. Antimicrobial and antioxidative activities in the bark extracts of sonneratia caseolaris, a mangrove plant. EXCLI Journal. 2014;13:997-1010.

8. Simlai A, Anjali G, Sarthaki AG, Amit R. Antimicrobial and antioxidative activities in the stem extracts of Derris trifoliata, a mangrove shrub. Journal of Pharmaceutical Research International. 2017;17(3):1-10.

9. Sudirman S, Nurjanah, Jacoeb AM. Proximate compositions, bioactive compounds and antioxidant activity from large-leafed mangrove (Bruguiera gymnorrhiza ). Fruit. 2014;21(6):2387-91.

10. Ramesh K, Natarajan M, Sridhar H, Vanitha MU, Umamaheswari S. Anti-vibrio activity of mangrove and mangrove associates on shrimp pathogen, Vibrio harveyi VSH5. Global Veterinaria. 2014;12(2):270-6.
11. Ulmursida A, Ambariyanto A, Trianto A. Antibacterial activity of mangrove avicennia marina leaves extract against Virgibacillus marismortui and Micrococcus luteus bacteria. AACL Bioflux. 2017;10(2):372-80.

12. Narendran R, Kandasamy K. Biocatalysis and agricultural biotechnology antimicrobial activity of crude extracts from mangrove-derived trichoderma species against human and fish pathogens. Biocatalysis and Agricultural Biotechnology. 2016;6:189-94.

13. Saad S, Taher M, Susanti D, Qaralleh H, Nurul A, Rahim A. Antimicrobial activity of mangrove plant (Lumnitzera littorea). Asian Pacific Journal of Tropical Medicine. 2011;4(7):523-5.

14. Amal MNA, Zamri-Saad M. Streptococcosis in Tilapia (Oreochromis niloticus) A review. Pertanika Journal of Tropical Agricultural Science. 2011;34(2):195-206.

15. Dong HT, Techatanakitarnan C, Jindakittikul P, Thaiprayoon A, Taengphu S, et al Aeromonas Jandaei and Aeromonas Veronii caused disease and mortality in nile tilapia, Oreochromis niloticus (L). Journal of Fish Diseases. 2017:1-9.

16. Frans I, Michiels CW, Bossier P, Willems KA, Lievens B, Rediers H. Vibrio Anguillarum as a fish pathogen: Virulence factors, diagnosis and prevention. Journal of Fish Diseases. 2011;34(9):643-61.

17. Pridgeon JW, Phillip HK. Major Bacterial diseases in aquaculture and their vaccine development. Cab Reviews. 2012;7(48):1-16.

18. Zhao XI, Han T, Ren ST, Ma YM, Li H, Peng XX. L-proline increases survival of tilapias infected by Streptococcus agalactiae in higher water temperature. Fish and Shellfish Immunology. 2015;44(1):33-42.

19. Defoirdt T, Sorgeloos P, Bossier P. Alternatives to antibiotics for the contro of bacterial disease in aquaculture. Currnet Opinion in Microbiology. $2011 ; 2(14): 251-8$

20. Santos L, Fernando R. Antimicrobial resistance in aquaculture: Current knowledge and alternatives to tackle the problem. International Journal of Antimicrobial Agents 2018;52(2):135-43.

21. Food and Agriculture Organization of the United Nations (FAO). Antimicrobial Resistance ( AMR ) in Aquaculture 2017.

22. Grenni P, Valeria A, Barra A. Ecological effects of antibiotics on natural ecosystems: A review. Microchemical Journal. 2018;136:25-39.

23. Turker $H$, Birinci $A$. Screening for antibacterial activity of some turkish plants against fish pathogens: A possible alternative in the treatment of bacteria infections. Biotechnology and Biotechnological Equipment. 2015;29(2):281-8.

24. Isnansetyo A, Kamei Y. MC21-A, A bactericidal antibiotic produced by a new marine against Methicillin-resistant Staphylococcus aureus. Antimicrobial Agents and Chemotherapy. 2003;47(2):480-8.

25. Isnansetyo A, Kamei Y. Direct antagonistic method for screening antiMethicillin-Resistant Staphylococcus aureus (MRSA) substance-producing marine bacteria. Biota. 2005;10:141-5.

26. Clinical and Laboratory Standards Institute (CLSI). Methods for dilution antimicrobial susceptibility tests for bacteria that grow aerobically; Approved standard-8 ${ }^{\text {th }}$ ed. CLSI document M07-A8. Wayne, PA;2009.

27. Arivuselvan J, Silambarasan D, Govindan T, Kathiresan K. Antibacterial activity of mangrove leaf and bark extracts against human pathogens. Adv Biol Res. $2011 ; 5(5): 251-4$.

28. Banerjee D, Chakrabarti S, Hazra AK, Banerjee S, Ray J, Mukerjee B. Antioxidant Activity and total phenolic of some mangrove in sunderbans. Afr J Biotechnol. 2008;7(6):805-10.

29. Castro SBR, Leal CAG, Freire FR, Carvalho DA, Oliveira DF, Figueiredo HCP. Antibacterial activity of plant extracts from brazil against fish. Brazilian Journal of Microbiology. 2008;39:756-60.

30. Kuete V, Nana F, Ngameni B, Tsafack A, Keumedjio F, Tchaleu B. Antimicrobial activity of the crude extract, fractions and compounds from stem bark of Ficus ovata (Moraceae). Ethnopharmacol J. 2009;124:556-61. 


\section{GRAPHICAL ABSTRACT}

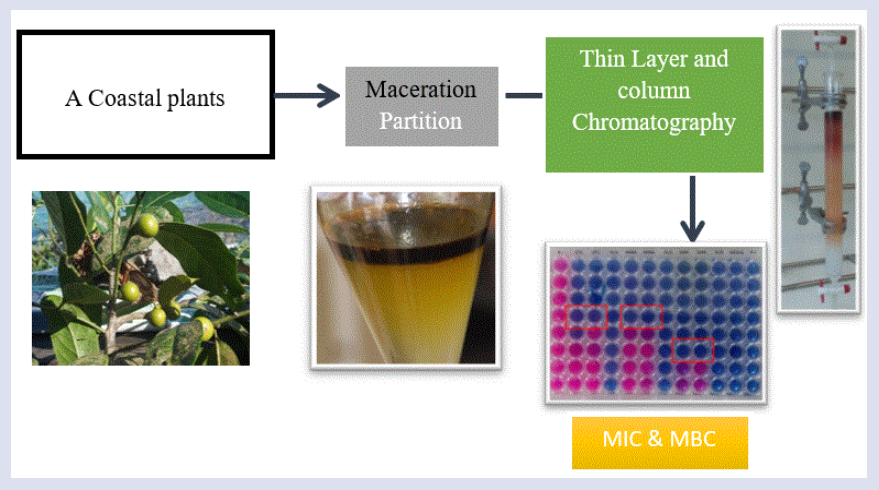

\section{SUMMARY}

- Three from a total of 32 coastal plants and marine sponges samples exhibited high antibacterial activity.

- The highest antibacterial activity was shown by the ethanol extract of the bark obtained from a coastal plant, Diospyros maritima.

- Antibacterial activity of purified substance from D. maritima was higher than commercial antibiotics against fish bacterial pathogens.

\section{ABOUT AUTHORS}
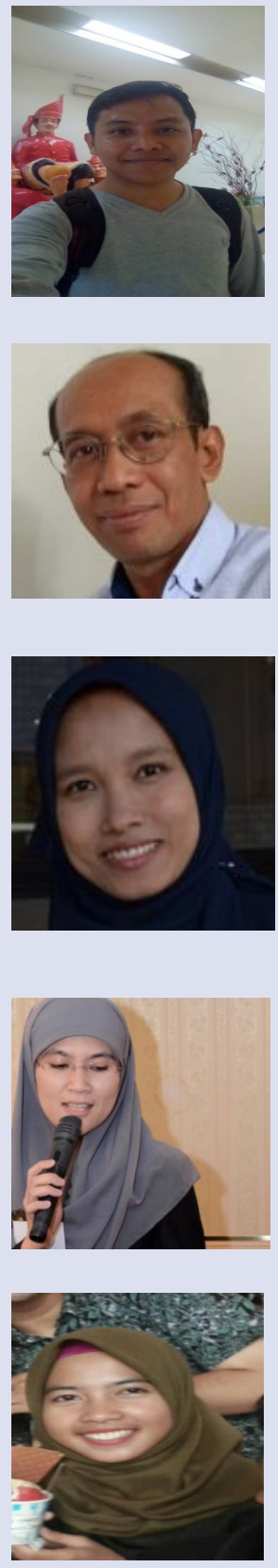

Andi Hamdillah: is a master student at study program of Fisheries Sciences, Faculty of Agriculture, Universitas Gadjah Mada, Yogyakarta, Indonesia. His master research focused on the screening and characterization of antibacterial substances of coastal plants and marine sponges against fish bacterial pathogen.

Dr. Alim Isnansetyo: is an Associate Professor at Fisheries Department, Faculty of Agriculture, Universitas Gadjah Mada, Yogyakarta, Indonesia. His research focused on Aquaculture, Immunology and Marine Biology/marine natural product.

Scopus Link: https://www.scopus.com/authid/detail.uri?authorld=6507970139

Google Scholar Link: https://scholar.google.co.id/citations?user=3fZJEFcAAAAJ\&hl=en

Dr. Indah Istiqomah: is a lecturer and researcher at Fisheries Department, Faculty of Agriculture, Universitas Gadjah Mada, Yogyakarta, Indonesia. She has experience in the area of Aquaculture, Immunology and Marine Biotechnology.

Indun Dewi Puspita Ph.D: is a lecturer and researcher at Fisheries Department, Faculty of Agriculture, Universitas Gadjah Mada, Yogyakarta, Indonesia. She conducts research in food science and technology, applied microbiology and food safety.

Desy Putri Handayani: is a doctoral student at study program of Fisheries Sciences, Faculty of Agriculture, Universitas Gadjah Mada, Yogyakarta, Indonesia. Her doctoral research focused on the screening, purification and characterization of antibacterial substance from marine microorganisms. 
Dr. Takushi Kaneko: is a Senior research fellow at theTB Alliance. He is responsible in the drug discovery research activities collaborating with pharmaceutical companies and academic institutions.

Cite this article: Hamdillah A, Isnansetyo A, Istiqomah I, Puspita ID, Handayani DP, Kaneko T. Antibacterial Activity of Coastal Plants and Marine Sponges from Kei Island Indonesia against Bacterial Fish Pathogen. Pharmacog J. 2019;11(4):812-7. 